\title{
Assessment of seroepidemic conditions of hepatitis B virus among people under 29 years of age and evaluation of the hepatitis $B$ vaccine after 22 years in Jiangsu Province, China
}

\section{xiang Sun ( $\mathbf{0}$ 365793124@QQ.com )}

Jiangsu Province Center for Disease Control and Prevention https://orcid.org/0000-0002-7211-2648

Yuanyuan Zhu

Jiangsu Provincial Center for Disease Control and Prevention

Fenyang Tang

Jiangsu Province Center for Disease Control and Prevention

Ying $\mathrm{Hu}$

Jiangsu Province Center for Disease Control and Prevention

Xiuying Deng

Jiangsu Province Center for Disease Control and Prevention

Zhiguo Wang

Jiangsu Province Center for Disease Control and Prevention

Yuanbao Liu

Jiangsu Province Center for Disease Control and Prevention

Minghao Zhou

Jiangsu Province Center for Disease Control and Prevention

Keywords:

Posted Date: January 16th, 2020

DOI: https://doi.org/10.21203/rs.2.15640/v2

License: (c) (i) This work is licensed under a Creative Commons Attribution 4.0 International License.

Read Full License 


\section{Abstract}

The authors have requested that this preprint be removed from Research Square. 